\title{
Insights into high-efficiency lignocellulolytic enzyme production by Penicillium oxalicum GZ-2 induced by a complex substrate
}

\author{
Hanpeng Liao, Shuixian Li, Zhong Wei, Qirong Shen and Yangchun Xu*
}

\begin{abstract}
Background: Agricultural residue is more efficient than purified cellulose at inducing lignocellulolytic enzyme production in Penicillium oxalicum GZ-2, but in Trichoderma reesei RUT-C30, cellulose induces a more efficient response. To understand the reasons, we designed an artificially simulated plant biomass (cellulose plus xylan) to study the roles and relationships of each component in the production of lignocellulolytic enzymes by P. oxalicum GZ-2.

Results: The changes in lignocellulolytic enzyme activity, gene expression involving (hemi)cellulolytic enzymes, and the secretome of cultures grown on Avicel (A), xylan (X), or a mixture of both (AX) were studied. The addition of xylan to the cellulose culture did not affect fungal growth but significantly increased the activity of cellulase and hemicellulase. In the AX treatment, the transcripts of cellulase genes (eg/1, eg/2, eg/3, sow, and cbh2) and hemicellulase genes $(x y / 3$ and $x y / 4)$ were significantly upregulated $(P<0.05)$. The proportion of biomass-degrading proteins in the secretome was altered; in particular, the percentage of cellulases and hemicellulases was increased. The percentage of cellulases and hemicellulases in the AX secretome increased from $4.5 \%$ and $7.6 \%$ to $10.3 \%$ and $21.8 \%$, respectively, compared to the secretome of the A treatment. Cellobiohydrolase II (encoded by cbh2) and xylanase II (encoded by $x y / 2$ ) were the main proteins in the secretome, and their corresponding genes (cbh2 and $x y / 2)$ were transcripted at the highest levels among the cellulolytic and xylanolytic genes. Several important proteins such as swollenin, cellobiohydrolase, and endo-beta-1,4-xylanase were only induced by AX. Bray-Curtis similarity indices, a dendrogram analysis, and a diversity index all demonstrated that the secretome produced by P. oxalicum GZ-2 depended on the substrate and that strain GZ-2 directionally adjusted the compositions of lignocellulolytic enzymes in its secretome to preferably degrade a complex substrate.

Conclusion: The addition of xylan to the cellulose medium not only induces more hemicellulases but also strongly activates cellulase production. The proportion of the biomass-degrading proteins in the secretome was altered significantly, with the proportion of cellulases and hemicellulases especially increased. Xylan and cellulose have positively synergistic effects, and they play a key role in the induction of highly efficient lignocellulolytic enzymes.
\end{abstract}

Keywords: Secretome, Penicillium oxalicum, Cellulose and xylan, Lignocellulolytic enzyme, Gene expression

\section{Background}

With the exhaustion of fossil fuels and the increasing global demand for fuel, the enzymatic conversion of lignocellulosic feedstocks into fermentable sugars has become an attractive alternative for clean and sustainable fuel production. Fungi are the major sources of lignocellulolytic

\footnotetext{
* Correspondence: ycxu@njau.edu.cn

National Enginnering Research Center for Organic-based Fertilizers, Jiangsu Collaborative Innovation Center for Solid Organic Waste Utilization, College of Resources and Environmental Science, Nanjing Agricultural University, Nanjing 210095, China
}

(c) 2014 Liao et al.; licensee BioMed Central Ltd. This is an Open Access article distributed under the terms of the Creative Commons Attribution License (http://creativecommons.org/licenses/by/4.0), which permits unrestricted use, distribution, and reproduction in any medium, provided the original work is properly credited. The Creative Commons Public Domain Dedication waiver (http://creativecommons.org/publicdomain/zero/1.0/) applies to the data made available in this article unless otherwise stated enzymes [1]. The lignocellulolytic enzymes used in enzymatic conversion mainly include cellulases and hemicellulases, which convert lignocellulolytic biomass into fermentable sugars. Although some progress has been made in enzyme production and in the enzymatic saccharification of lignocellulosic feedstocks, high cost is still the bottleneck hindering the industry's development [2].

Over the past decades, many high-production cellulolytic fungi have been isolated and reported [3,4]. However, there have been relatively few reports concerning the induction and repression mechanisms of lignocellulolytic 
enzymes on complex substrates. High-yield lignocellulolytic enzyme production requires a corresponding substance as an inducer for the fungi. In general, cellulose is an effective inductive substrate for the production of cellulase by many filamentous fungi such as Trichoderma spp., Aspergillus spp., and Penicillium spp. Cellulose itself cannot directly trigger the induction of lignocellulolytic enzymes because it is insoluble [5]. Soluble saccharides such as cellobiose, sophorose, lactose, sorbose, and galactose have been demonstrated to induce cellulase synthesis in Trichoderma reesei [6-9]. Hemicellulase is usually induced by hemicellulolytic polymers. Xylans are the most effective inducers for xylanase production. However, the specificities in the induction of cellulase and hemicellulase have not been well characterized when a complex substrate is used as the inducer. Although cellulose is a good substrate for inducing cellulases, other enzymes like xylanase are also produced [10]. Trichoderma longibrachiatum cultured on a mixture of lactose $(0.8 \%)$ and xylan $(0.2 \%)$ was found to result in significantly higher levels of both xylanase and cellulase than did cultures on either substrate alone [11]. These reports suggested that complicated interactions exist in the induction of these enzymes.

Agricultural wastes are renewable and abundant worldwide, and they are available for use as cheap feedstock to produce biomass-degrading enzymes. Applications of these enzymes to saccharify plant biomass for the production of bioethanol have been reported elsewhere [12-14]. Many reports have found that agricultural wastes are superior to pure cellulose at inducing biomassdegrading enzymes in many fungi $[15,16]$. However, a comprehensive understanding of why a complex substrate can induce more biomass-degrading enzymes and how fungi respond to complex lignocellulose during enzyme production is still lacking. The regulation and secretion features of Trichoderma and Aspergillus have been well studied and characterized [17-19]. Recently, researchers have investigated how fungi respond to plant biomass and the mechanism behind this response using the model strain Aspergillus niger [20-22]. Many researchers have previously investigated the secretome and transcriptome of Trichoderma spp. and Aspergillus spp. induced by different types of plant biomass [10,23-26]. However, the mechanisms of enzymatic induction in different fungi display clear similarities but also exhibit differences in the regulation of the expression of cellulase- and hemicellulaseencoding genes [27]. In our previous studies, the lignocellulolytic enzyme activity induced by agricultural waste was significantly higher than that induced by purified cellulose from $P$. oxalicum GZ-2. However, this feature did not exist in strain T. reesei RUT-C30 (data not published in our lab), suggesting that $P$. oxalicum GZ-2 possibly has different regulation and induction mechanisms for producing lignocellulolytic enzymes.
Understanding how the filamentous fungus $P$. oxalicum GZ-2 responds to plant biomass and induces an enzyme cocktail to degrade plant polymers may result in new strategies to improve the production of secondgeneration biofuels. The relationships and roles of each complex plant biomass component (such as cellulose and xylan) in inducing and regulating lignocellulosedegrading enzyme gene expression and protein profiles are still poorly understood. Therefore, an artificially mixed substrate containing a mixture of Avicel and xylan was designed to simulate plant biomass in this study. The objective of this work was to investigate how inducible hydrolytic enzymes respond to cellulose and xylan and their relationships and roles in protein expression along with the activity of lignocellulolytic enzymes.

\section{Results}

\section{Enzymatic activities induced by different substrates}

The production of various enzymes by $P$. oxalicum GZ-2 was evaluated in a time course when glucose (G), Avicel (A), xylan (X), and a mixture of Avicel and xylan (AX) were used as the sole carbon source, and the results are shown in Figure 1. The highest activities of FPase, CMCase, and xylanase were obtained in the AX treatment, and the enzymatic activities of beta-glucosidase, beta-xylosidase, and cellobiohydrolase induced by AX were at the intermediate level. These enzymatic activities were the lowest in the G treatment. On day 7, the xylanase activity in the AX treatment was 3.5 and 6.5 times higher than that in the $\mathrm{X}$ and $\mathrm{A}$ treatments, respectively. The FPase, CMCase, and xylanase activities of T. reesei RUT-C30 are shown in Additional file 1: Figure S1. As expected, A and X were the best substrates for cellulase and xylanase production, respectively; the addition of xylan to the cellulose medium significantly decreased the FPase activity but had little effect on the xylanase activity (Additional file 1: Figure S1A).

To determine whether the increase in enzymatic activity by $\mathrm{AX}$ was due to an increase in fungal biomass from P. oxalicum GZ-2, we examined the growth behavior of P. oxalicum GZ-2 on various substrates. As shown in Additional file 2: Figure S2A, the growth of $P$. oxalicum GZ-2 on AX occurred at a slightly faster rate but with no significant difference before the third day. The fungal cells on A always increased with time and peaked at the end of the fermentation. The protein concentrations in the four substrates were determined and are shown in Additional file 2: Figure S2B. The maximum protein content $(2.2 \mathrm{mg} / \mathrm{mL})$ was found in the $\mathrm{AX}$ treatment during the later period of fermentation.

\section{Protein profiles in the culture supernatant}

The protein profile by SDS-PAGE is shown in Figure 2A1. Automatic detection of the bands using Quantity One 

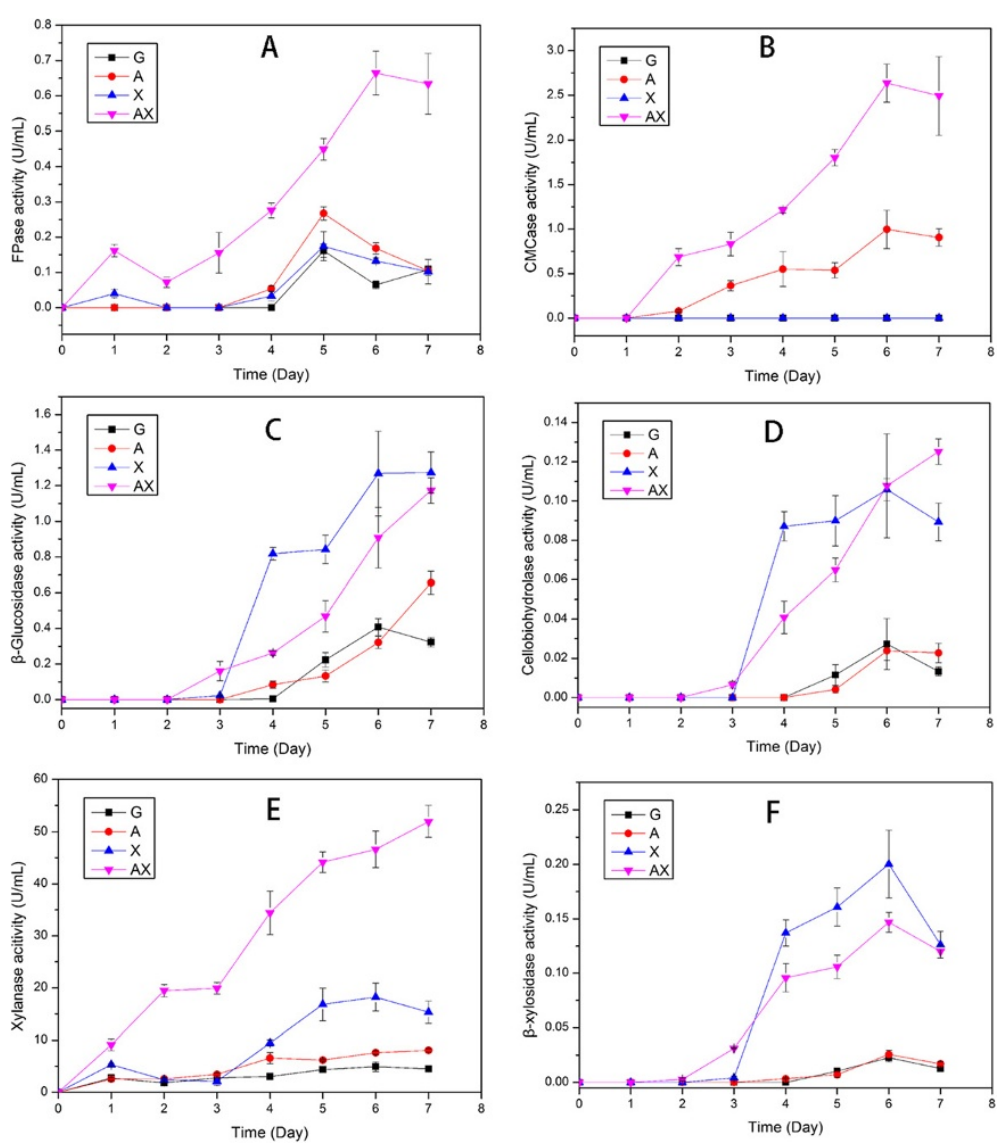

Figure 1 Lignocellulolytic enzyme activities in the extracellular culture supernatant of $P$. oxalicum GZ-2 in the presence of different substrates. Time courses of the enzyme activities of the various culture supernatants from P. oxalicum GZ-2 were determined during submerged fermentation for 7 days at $30^{\circ} \mathrm{C}$. The activities of FPase, CMCase, beta-glucosidase, cellobiohydrolase, xylanase, and beta-xylosidase are listed in A, B, C, D, E, and $\mathbf{F}$, respectively. The error bars indicate the standard deviation of three replicates.

(Bio-Rad, USA) is shown in Figure 2A2. More protein bands were detected in the $\mathrm{A}, \mathrm{X}$, and AX lanes than in the $\mathrm{G}$ lane. Zymographic analysis demonstrated that more than eight, five, and nine protein bands with cellulase activity were observed in the $\mathrm{A}, \mathrm{X}$, and $\mathrm{AX}$ lanes, respectively (Figure 3A1). In the $G$ lane, there were only three weak bands. As shown in Figure 3A1, the lanes AX and A have the same number of CMCase-active bands, but the pale-red hydrolysis zones of lane AX are clearly larger than those of lane A. In comparison with lane X, lane AX showed not only more protein bands but also clearly increased abundance of the protein bands. The bands from lane AX were excised, trypsin-digested, and further identified using matrix-assisted laser desorption/ionization time-of-flight tandem mass spectrometry (MALDI-TOFMS/MS). The results in Table 1 indicate that most of the identified proteins are cellulases but also have other glycoside hydrolases. The hemicellulolytic profile of enzymes with xylanase activity analyzed by zymogram is shown in Figure 3A2. Similar to the cellulase zymogram, the greatest number of xylanase-active bands (ten bands) was observed in the AX lane, whereas no bands were found in the G lane. The MALDI-TOF-MS/MS identification results suggest that abundant hemicellulases such as putative endo-beta-1,4-xylanases, beta-1,4-mannanase, and alpha-L-arabinofuranosidase were found. We used in-gel activity assays to detect beta-glucosidase and cellobiohydrolase activity, and the results are shown in Figure 3A3,A4. In four lanes, one band showed betaglucosidase activity in each lane, but the hydrolysis zone of the AX lane was the brightest. For cellobiohydrolase, one band was detected in each lane except for lane G.

\section{Transcript levels of lignocellulose-degrading genes in different substrates}

The transcript levels of lignocellulose-degrading genes in $P$. oxalicum GZ-2 under different substrate treatments are shown in Figure 4. The transcript profiles were determined on the second day because the growth of fungus GZ-2 nearly stopped after day 3 . In the four substrate treatments, the studied genes encoding cellulosedegrading enzymes were transcribed at various levels 


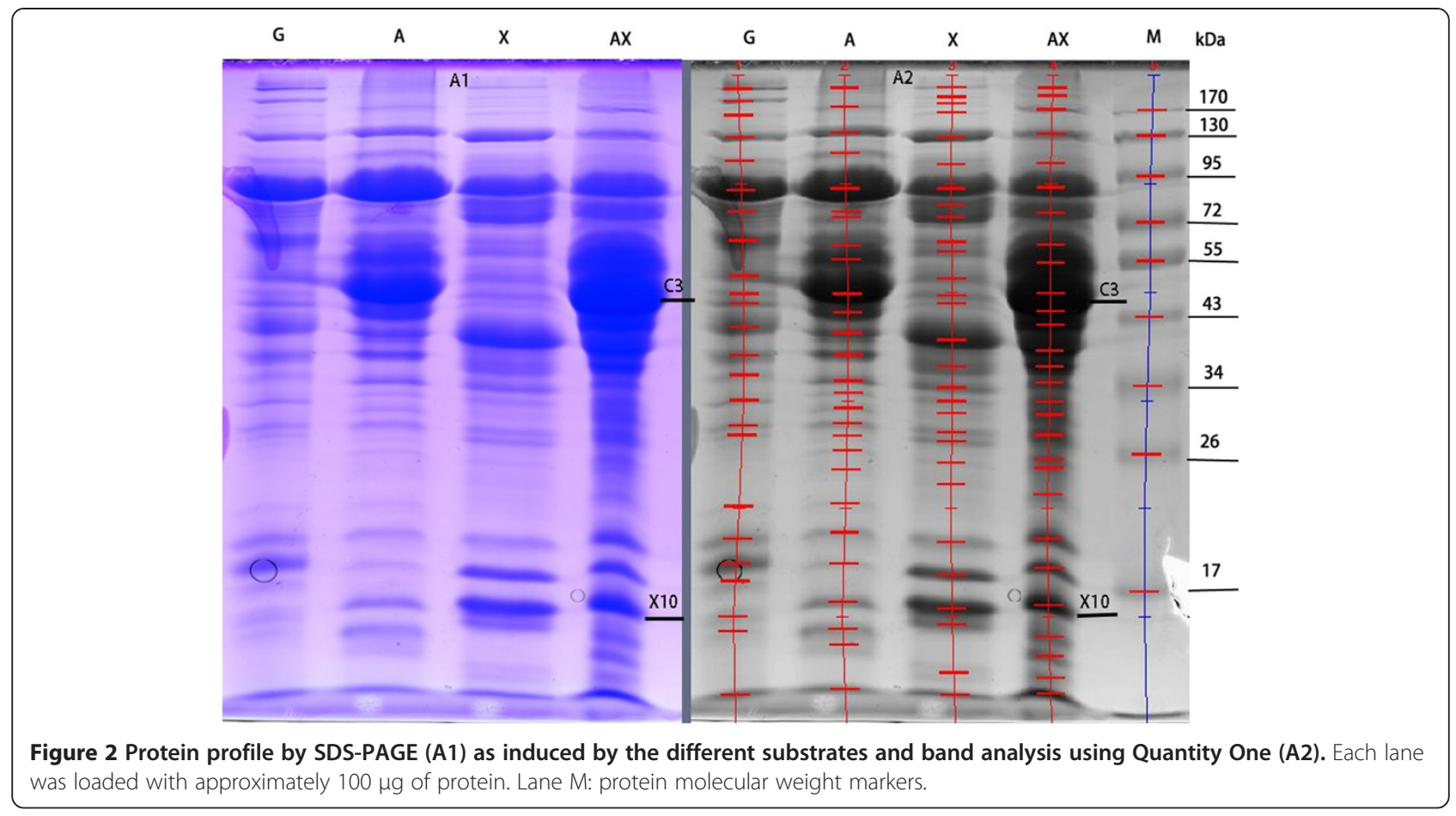

(Figure 4A). The genes were transcribed to a significantly higher level under the $\mathrm{A}, \mathrm{X}$, and $\mathrm{AX}$ treatments than under the $\mathrm{G}$ treatment. The level of the $c b h 2$ transcript was significantly higher than those of the other enzyme-encoding genes in all the treatments. Similarly, significantly higher transcript levels of egl1, egl2, egl3, sow, and cbh2 were detected in the AX treatment than in the A or X treatment $(P<0.01)$. Unexpectedly, the highest level of the $b g l$ transcript was observed in the $\mathrm{X}$ treatment. The expression level of $c b h 1$ was maintained at a low level in all treatments. A very low level of constitutive expression was observed for all the genes when $G$ was used as a substrate.

All substrates (G, A, X, and AX) induced the expression of all the hemicellulolytic genes $(x y l 1, x y l 2, x y l 3$, $x y l 4, \operatorname{arf}, b-x$, and $m a)$ at various levels (Figure 4B). The most highly expressed gene among all the hemicellulolytic genes was $x y l 2$. Expectedly, the expression of all the hemicellulolytic genes was significantly higher with the polymeric substrate than with glucose (at least $P<0.05$ ).
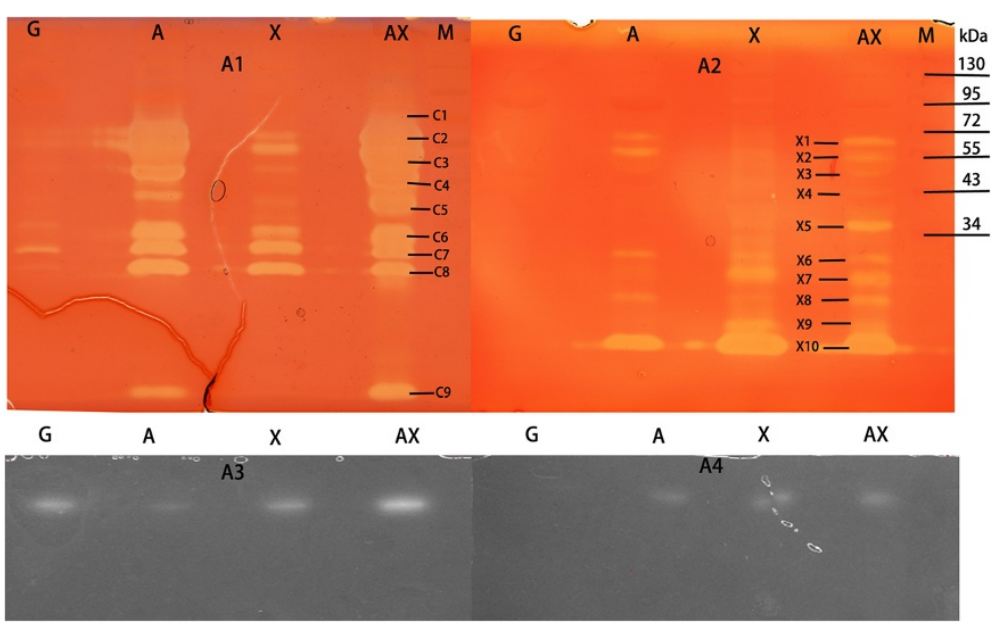

Figure 3 Zymographic analysis of the expression of lignocellulolytic enzymes. Zymographic analysis of the expression of endoglucanase (A1), xylanase (A2), beta-glucosidase (A3), and cellobiohydrolase (A4) in the culture supernatant from P. oxalicum GZ-2 grown on different substrates. Lane M: protein molecular weight markers. 
Table 1 Zymogram bands identification analysis using MALDI-TOF-MS/MS

\begin{tabular}{|c|c|c|c|c|c|}
\hline Denotation & Predicted protein function & Family & Signal peptides & Protein score & Accession number \\
\hline $\mathrm{C} 1$ & Exo-beta-1,3-glucanase & Pectate_lyase_3 & Y & 138 & 525586927 \\
\hline \multirow[t]{2}{*}{$\mathrm{C} 2$} & Alpha-amylase Amy13A & Alpha-amylase & Y & 51 & 525580015 \\
\hline & Glucoamylase Amy15A & $\mathrm{GH} 15$ & Y & 60 & 525588203 \\
\hline \multirow[t]{3}{*}{ C3 } & Cellobiohydrolase CBHI/Cel7A-2 & $\mathrm{GH} 7$ & Y & 143 & 525586734 \\
\hline & Swollenin & nd & Y & 41 & 525580909 \\
\hline & Exo-beta-1,3-glucanase & $\mathrm{GH} 17$ & Y & 25 & 525581916 \\
\hline \multirow[t]{2}{*}{ C4 } & Cellobiohydrolase Cel6A & GH6 & Y & 39 & 525585914 \\
\hline & Beta-1,4-mannanase & GH5 & Y & 80 & 525584819 \\
\hline C5 & Endo-beta-1,4-glucanase & GH5 & Y & 231 & 525588012 \\
\hline C6 & Hypothetical protein PDE_07927 & nd & Y & 57 & 525586716 \\
\hline C7 & Hypothetical protein PDE_06814 & nd & Y & 105 & 525585606 \\
\hline $\mathrm{C} 8$ & Endo-beta-1,4-xylanase & $\mathrm{GH} 11$ & Y & 145 & 525580908 \\
\hline C9 & nd & nd & nd & nd & nd \\
\hline $\mathrm{X}_{1}$ & Glucoamylase Amy15A & $\mathrm{GH} 15$ & Y & 47 & 525588203 \\
\hline \multirow[t]{3}{*}{$x 2$} & Cellobiohydrolase CBHI/Cel7A-2 & $\mathrm{GH} 7$ & Y & 150 & 525586734 \\
\hline & Endo-beta-1,4-xylanase & $\mathrm{GH} 30$ & Y & 103 & 525578833 \\
\hline & Exo-beta-1,3-glucanase & GH17 & Y & 25 & 525581916 \\
\hline X3 & Cellobiohydrolase Cel6A & GH6 & Y & 39 & 525585914 \\
\hline \multirow[t]{3}{*}{$\mathrm{X} 4$} & Beta-1,4-mannanase & $\mathrm{GH} 5$ & Y & 143 & 525584819 \\
\hline & Endo-beta-1,4-glucanase & GH5 & Y & 121 & 525588012 \\
\hline & Hypothetical protein PDE_07927 & nd & Y & 163 & 525586716 \\
\hline$x_{5}$ & Alpha-L-arabinofuranosidase & GH62 & Y & 193 & 525578835 \\
\hline$x_{6}$ & Beta-1,3-glucanosyltransferase & $\mathrm{GH} 17$ & Y & 28 & 525579431 \\
\hline $\mathrm{X} 7$ & Endo-beta-1,4-xylanase & GH11 & Y & 144 & 525580908 \\
\hline $\mathrm{X} 8$ & Lysozyme & $\mathrm{GH} 25$ & Y & 42 & 525582100 \\
\hline$x 9$ & Endo-beta-1,4-xylanase & GH11 & Y & 173 & 525583278 \\
\hline $\mathrm{X} 10$ & Endo-beta-1,4-xylanase & $\mathrm{GH} 11$ & Y & 93 & 525583278 \\
\hline
\end{tabular}

nd not detected; $Y$ means with signal peptides; $G H$ glycoside hydrolase.

Interestingly, the transcript levels of the genes $x y l 3$ and $x y l 4$ were induced significantly more by AX than by the other substrates (at least $P<0.05$ ). No transcript level difference of $x y l 1$ existed between the X and AX treatments, but it was significantly higher than that in the A treatment $(P<0.01)$. The expression levels of $\operatorname{arf}$ and $b-x$ were induced significantly more by $\mathrm{X}$ than by the other substrates. However, it is noteworthy that A was the substrate that most strongly induced the expression of $m a$.

The secretome of $P$. oxalicum GZ-2 as induced by different substrates

Because the zymogram does not accurately show changes of a single protein, liquid chromatography-tandem mass spectrometry (LC-MS/MS) was used to analyze and identify the secretomes induced by different substrates. In the Venn diagram (Figure 5), 108 of the identified proteins $(42.5 \%)$ exclusively existed in just one condition. A comparison of the four secretomes illustrates that 131 of the identified proteins (51.6\%) were shared by two or three cultures. However, only 34 proteins were present in all four secretomes, corresponding to $13.4 \%$ of all the proteins (Additional file 3: Table S1). The proteins identified in the secretome of $P$. oxalicum GZ-2 grown on different substrates (G, A, X, and AX) are listed in Additional file 4: Table S2. As shown in Figure 6, the proteins identified in the secretomes were functionally grouped into cellulases, hemicellulases, other glycoside hydrolases, pectinases and chitinases, cell wall biosynthesis and metabolism proteins, hypothetical proteins, and other proteins. The percentage of cellulases was $1.0 \%, 4.5 \%, 5.0 \%$, and $10.3 \%$, respectively, in the G, A, X, and AX secretomes. The percentage of hemicellulases in the G, A, X, and AX secretomes was $5.9 \%, 7.6 \%, 12.1 \%$, and $21.8 \%$, respectively. The distributions of the molecular weights and isoelectric points of the identified proteins are shown in Additional file 5: 


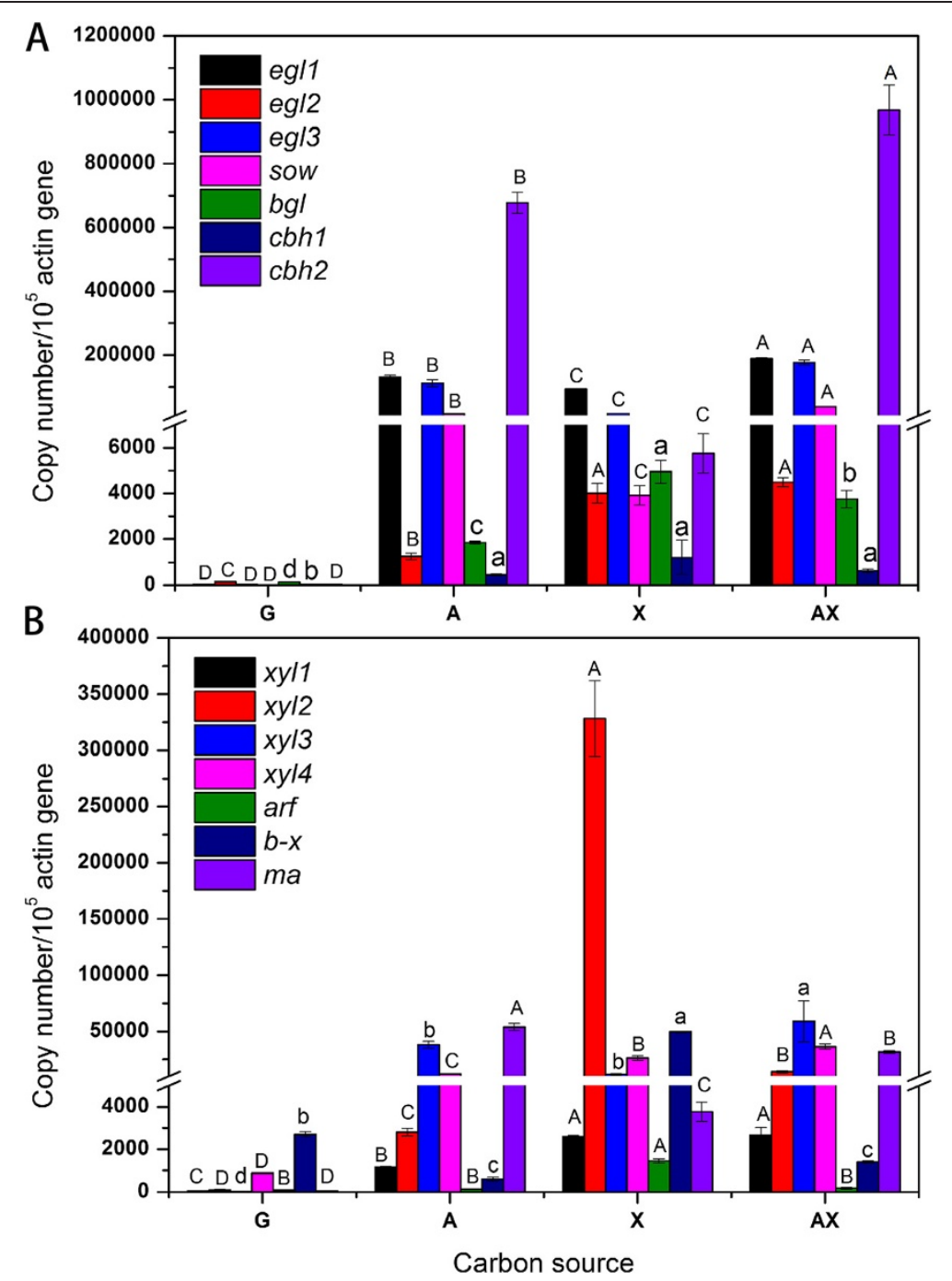

Figure 4 Cellulolytic (A) and hemicellulolytic (B) enzyme gene expression levels of $P$. oxalicum GZ-2 grown on different substrates for $48 \mathrm{~h}$. The error bars indicate the standard deviation of three replicates. Values in different treatments followed by the same letter are not significantly different according to Tukey's honest significant difference (HSD) test (capital letters indicate $P<0.01$; lowercase letters indicate $P<0.05)$.

Figure S3. The molecular weights of most of the identified proteins ranged from 15 to $150 \mathrm{kDa}$, and their isoelectric points ranged from 4.0 to 11.5 . The similarity value among lignocellulose-degrading proteins (cellulases and hemicellulases) secreted on the A, X, and AX substrates, respectively, by the Bray-Curtis algorithm was $>70 \%$ (Table 2). However, the similarity value was $<50 \%$ between the lignocellulose-degrading proteins (cellulases and hemicellulases) induced by $G$ and the other substrates. The clustering pattern of cellulases, hemicellulases, and other proteins is presented in Figure 7. The expression pattern of cellulases and hemicellulases induced by AX was clustered with A and X, while G formed another separate cluster (Figure 7A). However, the expression pattern of other glycoside hydrolases, cell wall biosynthesis metabolism proteins, and hypothetical proteins induced by $\mathrm{G}$ was clustered with $\mathrm{A}$ and $\mathrm{X}$, and another separate cluster was formed by AX. The effects of the various substrates on the diversity of the functional proteins expressed by $P$. oxalicum GZ-2 were further evaluated using the Shannon-Wiener index $(\mathrm{H})$ and the Simpson diversity index (D) (Additional file 6: Table S3). The $\mathrm{H}$ index of the identified proteins induced by G, A, X, and AX was $0.64,0.63,0.60$, and 0.76 , respectively. The D index of the identified proteins induced by G, A, X, and AX was 1.96, 1.98, 1.93, and 2.27, respectively.

A total of 101 proteins were identified when GZ-2 was grown in a medium containing $1 \%(\mathrm{w} / \mathrm{v}) \mathrm{G}$, and 26 proteins were only induced by G. Only one cellulase (betaglucosidase BGL1, 525581542) was identified in the G 


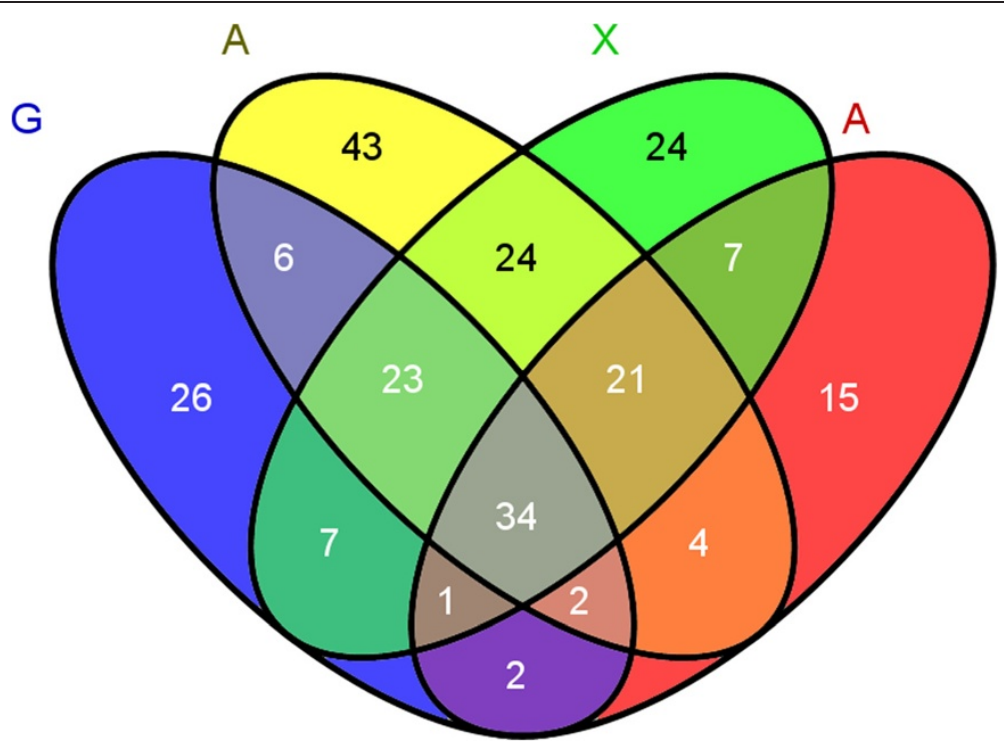

Figure 5 Venn diagram representing unique and common proteins identified in the $P$. oxalicum GZ-2 secretome as induced by different substrates. A total of 254 nonredundant protein groups were identified in the secretomes that resulted from growth in media containing G (glucose), A (Avicel), X (xylan), or AX (Avicel and xylan) using gel-free LC-MS/MS. The Venn diagram was prepared using Venny online tools.

culture. In the secretome obtained from the A culture, 157 proteins were identified, and 43 proteins were only induced by A. Three major types of cellulase (endoglucanase, beta-glucosidase, and cellobiohydrolase) and many hemicellulases were present in this secretome. A total of 141 proteins were identified, and 24 proteins exclusively existed in the X secretome. In the secretome of AX, 86 proteins were identified, 15 of which were only induced by AX. Two cellulases (swollenin and cellobiohydrolase) and four hemicellulases were specifically induced by AX.

\section{Expression and identification of cellulolytic proteins}

Complete cellulose degradation requires three major cellulases: endo-1,4-beta-glucanase, exo-1,4-beta-glucanase,

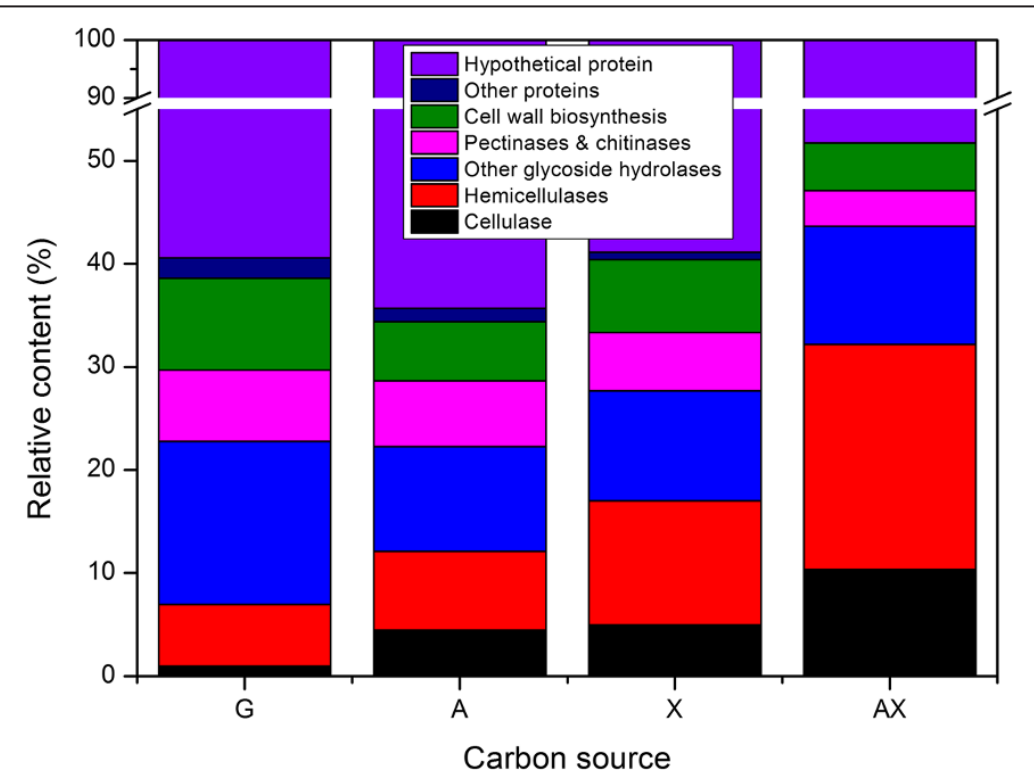

Figure 6 Functional classification and relative proportion of the LC-MS/MS-identified proteins in the secretomes induced by the different substrates. 
Table 2 Bray-Curtis similarity indices of the protein profile by $P$. oxalicum GZ-2 on different substrates

\begin{tabular}{lllll}
\hline Cellulases & G & A & X & AX \\
\hline G & 100 & & & \\
A & 25 & 100 & & \\
X & 25 & 100 & 100 & \\
AX & 20 & 87.5 & 87.5 & 100
\end{tabular}

Hemicellulases

$\begin{array}{lllll}\text { G } & 100 & & & \\ \text { A } & 44.44 & 100 & & \\ X & 43.48 & 82.76 & & \\ \text { AX } & 40 & 70.97 & 77.78 & 100\end{array}$

Other glycoside hydrolases

\begin{tabular}{|c|c|c|c|c|}
\hline G & 100 & & & \\
\hline A & 90.32 & 100 & & \\
\hline$x$ & 80 & 89.66 & 100 & \\
\hline$A X$ & 56 & 66.67 & 69.57 & 100 \\
\hline \multicolumn{5}{|c|}{$\begin{array}{l}\text { Pectinases and } \\
\text { chitinases }\end{array}$} \\
\hline G & 100 & & & \\
\hline A & 55.56 & 100 & & \\
\hline$x$ & 50 & 90 & 100 & \\
\hline$A X$ & 54.55 & 53.33 & 61.54 & 100 \\
\hline \multicolumn{5}{|c|}{$\begin{array}{l}\text { Cell wall biosynthesis } \\
\text { metabolism proteins }\end{array}$} \\
\hline G & 100 & & & \\
\hline A & 88.89 & 100 & & \\
\hline$x$ & 84.21 & 94.74 & 100 & \\
\hline$A X$ & 61.54 & 61.54 & 57.14 & 100 \\
\hline \multicolumn{5}{|c|}{ Hypothetical proteins } \\
\hline G & 100 & & & \\
\hline A & 49.23 & 100 & & \\
\hline$x$ & 39.46 & 52.07 & 100 & \\
\hline$A X$ & 40.43 & 46.55 & 40.6 & 100 \\
\hline
\end{tabular}

and beta-glucosidase. The greatest number of cellulosedegrading enzymes (nine cellulases) including three major cellulases, swollenin, and cellulose monooxygenase $(\mathrm{Cel} 61 \mathrm{~A})$ were identified in the AX secretome. The proportion of cellulases in the AX secretome (10.3\%) was more than twofold greater than that of the A $(4.5 \%)$ or X (5.0\%) secretome. The same number of cellulases (seven) was identified in the $\mathrm{A}$ and $\mathrm{X}$ secretomes. Only one cellulase was detected when $P$. oxalicum GZ-2 was grown on $\mathrm{G}$. The comparative quantitative expression abundances of the cellulolytic proteins on the different substrates are presented in Table 3. The AX/A ratios of the putative beta-1,3-1,4-glucanase, cellulose monooxygenase Cel61A, and cellobiohydrolase Cel6A were 4.46,
2.12, and 7.15, respectively. The expression of most cellulases was strongly upregulated in the AX treatment compared to that in the $\mathrm{X}$ treatment. The abundance of most cellulases was more than 100 -fold higher in the AX treatment than in the $\mathrm{X}$ treatment.

\section{Expression and identification of hemicellulases and glycoside hydrolases}

The degradation of complex hemicelluloses requires several synergistic actions of different hemicellulases including xylanases, beta-xylosidase, beta-1,4-mannanase, acetyl xylan esterase, and alpha-L-arabinofuranosidase. These enzymes were present when $P$. oxalicum GZ-2 was grown on polymeric substrates (Additional file 4: Table S2). The numbers of identified proteins involved in hemicellulose degradation were $6,12,17$, and 19 in the G, A, X, and AX treatments, respectively, and two putative alpha-Larabinofuranosidases (525578834 and 525586375), a putative endo-beta-1,4-xylanase (525581488), and a putative acetyl xylan esterase (525588064) were only induced by $\mathrm{AX}$. The $\mathrm{AX} / \mathrm{X}$ ratios of the putative beta-1,4-mannanase (525584819), the putative endo-beta-1,4-xylanase (525578833), and the putative endo-beta-1,4-xylanase (525586882) were 4.9, 33.5, and 3.4, respectively. Various numbers of putative endo-beta-1,4-xylanases $(5,5,4$, and 1) were identified in the $P$. oxalicum GZ-2 secretomes induced by AX, X, A, and G, respectively. GH30 (previously classified into GH5) endo-beta-1,4-xylanase and GH3 beta-xylosidase are constitutively expressed using $G$ as a substrate. The comparative expression abundances of the hemicellulolytic proteins cultured with various substrates are presented in Table 4. The AX/A ratios of the putative endo-beta-1,4-xylanase (525578833), the putative endo-beta-1,4-xylanase (525578833), the putative acetyl xylan esterase (525582983), the putative alpha-Larabinofuranosidase (525584862), and the putative exobeta-1,3-galactanase (525588065) were 2.9, 3.0, 9.1, 2.5, and 1.9, respectively. GH30 putative endo-beta-1,4-xylanase (525578833), GH11 putative endo-beta-1,4-xylanase (5255 80908), GH10 putative endo-beta-1,4-xylanase (5255 86882), putative alpha-L-arabinofuranosidase (52557 8835), and putative beta-1,4-mannanase (525584819) were upregulated when $P$. oxalicum GZ-2 was cultured with $\mathrm{AX}$ compared to $\mathrm{X}$, and the $\mathrm{AX} / \mathrm{X}$ ratios were $33.5,1.4,3.4,2.4$, and 4.9, respectively. Many other glycoside hydrolases involved in the hydrolysis of glycosidic bonds were identified in the GZ-2 secretome. Although no starch is present in any of the substrates, amylase and glucoamylase were identified in the A, X, and AX secretomes.

Expression and identification of pectinases and chitinases This study identified nine pectin-degrading enzymes and four chitin-hydrolyzing enzymes (Additional file 4: 


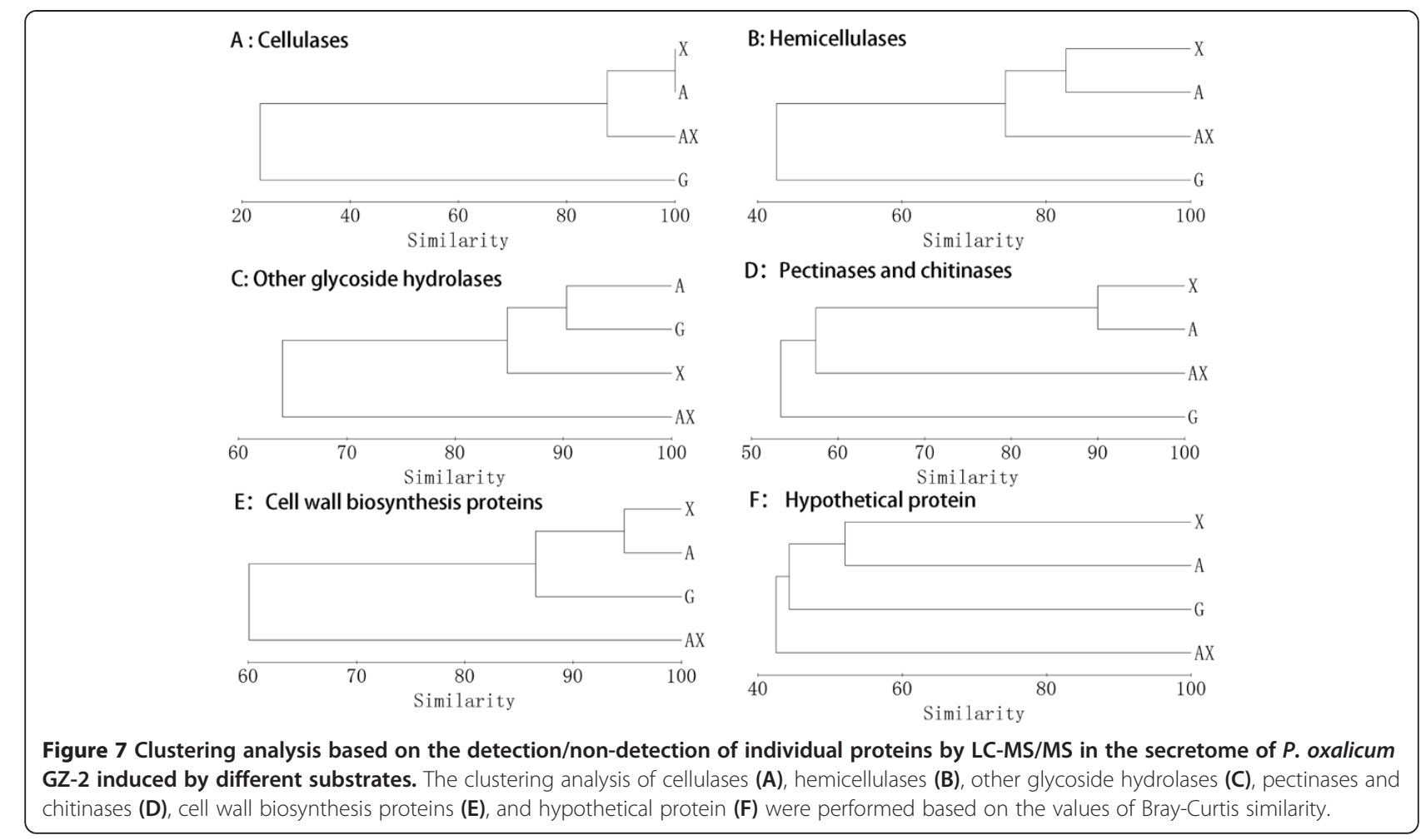

Table S2). Only two pectinases and two chitinases were present in the secretome of AX. In the A secretome, 11 proteins involved in the degradation of pectin and chitin were identified, suggesting that $\mathrm{A}$ is the best substrate for the production of these enzymes. The number of proteins identified involved in the degradation of pectin and chitin was nine and seven in the $\mathrm{X}$ and $\mathrm{G}$ secretomes, respectively.

\section{Discussion}

In a previous study, we found that $P$. oxalicum GZ-2 uses agricultural waste (corn stover) more efficiently than purified cellulose to produce cellulase. In contrast, $T$. reesei RUT-C30 was found to be more effective at secreting cellulolytic enzymes with purified cellulose as an inducer (data not published). As we know, cellulose is one of the most suitable substrates to induce cellulases for many fungi, especially for $T$. reesei RUT-C30 $[1,28]$. This interesting characteristic suggested that the induction and regulation mechanisms of $P$. oxalicum GZ-2 were different from those of $T$. reesei RUT-C30. The reasons why agricultural waste induces more enzymes for $P$. oxalicum GZ-2 are unclear. We hypothesize that xylan as the major component in the hemicellulose synergizes with cellulose to enhance lignocellulolytic enzyme induction. To validate this hypothesis and further evaluate the influence of the composition of complex substrates on enzyme induction, an artificial substrate containing a mixture of Avicel and

Table 3 Label-free quantitative analysis of cellulolytic enzymes expression using SIEVE software

\begin{tabular}{|c|c|c|c|c|c|c|c|}
\hline Accession & Predicted protein function & Signal peptides & Family & Ratio AX/A & $P$-value & Ratio $\mathrm{AX} / \mathrm{X}$ & $P$-value \\
\hline 525580909 & Swollenin & Y & nd & nd & nd & nd & nd \\
\hline 525584244 & Cellobiohydrolase & Y & $\mathrm{GH} 7$ & nd & nd & nd & nd \\
\hline 525581542 & Beta-glucosidase & Y & $\mathrm{GH} 3$ & 1.05 & $9.90 \mathrm{E}-20$ & 82.65 & $2.29 \mathrm{E}-06$ \\
\hline 525581794 & Beta-1,3-1,4-glucanase & Y & GH16 & 4.46 & $2.95 \mathrm{E}-08$ & 0.65 & 0.9994203 \\
\hline 525584431 & Cellulose monooxygenase & Y & GH61 & 2.13 & 7.40E-07 & 1.14 & 0.8792061 \\
\hline 525585914 & Cellobiohydrolase & Y & GH6 & 7.15 & $8.39 \mathrm{E}-14$ & 166.96 & 4.00E-11 \\
\hline 525586734 & Cellobiohydrolase & Y & $\mathrm{GH} 7$ & 0.80 & $9.90 \mathrm{E}-20$ & 607.47 & $9.90 \mathrm{E}-20$ \\
\hline 525588012 & Endo-beta-1,4-glucanase & Y & GH5 & 1.50 & 0.0002096 & 358.05 & $6.20 \mathrm{E}-12$ \\
\hline 525588754 & Endo-beta-1,4-glucanase & Y & GH5 & 1.33 & 0.0011941 & 147.03 & $3.54 \mathrm{E}-08$ \\
\hline
\end{tabular}

nd not detected; $\mathrm{Y}$ means with signal peptides; $G H$ glycoside hydrolase. 
Table 4 Label-free quantitative analysis of hemicellulolytic enzymes expression by SIEVE

\begin{tabular}{|c|c|c|c|c|c|c|c|}
\hline Accession & Predicted protein function & $\begin{array}{l}\text { Signal } \\
\text { peptides }\end{array}$ & Family & Ratio AX/A & $P$-value & Ratio AX/X & $P$-value \\
\hline 525582983 & Acetyl xylan esterase & Y & Cutinase & 9.07 & 9.90E-20 & 0.05 & 0.5983891 \\
\hline 525578835 & Alpha-L-arabinofuranosidase & Y & GH62 & nd & nd & 2.43 & $9.90 \mathrm{E}-20$ \\
\hline 525584862 & Alpha-L-arabinofuranosidase & Y & $\mathrm{GH} 43$ & 2.49 & 0.0027907 & 0.11 & 0.0266966 \\
\hline 525584819 & Beta-1,4-mannanase & Y & $\mathrm{GH} 5$ & 0.36 & $9.90 \mathrm{E}-20$ & 4.94 & $1.75 \mathrm{E}-11$ \\
\hline 525578868 & Beta-xylosidase & Y & $\mathrm{GH} 3$ & 0.09 & 9.90E-20 & 0.07 & $1.59 E-05$ \\
\hline 525588496 & Beta-xylosidase & Y & $\mathrm{GH} 3$ & 0.27 & $1.15 \mathrm{E}-05$ & nd & nd \\
\hline 525578833 & Endo-beta-1,4-xylanase & Y & $\mathrm{GH} 30$ & 2.99 & 9.90E-20 & 33.54 & $3.86 \mathrm{E}-12$ \\
\hline 525580908 & Endo-beta-1,4-xylanase & Y & $\mathrm{GH} 11$ & nd & nd & 1.44 & 5.25E-09 \\
\hline 525581225 & Endo-beta-1,4-xylanase & Y & $\mathrm{GH} 10$ & nd & nd & nd & nd \\
\hline 525583278 & Endo-beta-1,4-xylanase & Y & $\mathrm{GH} 11$ & 1.93 & $9.90 \mathrm{E}-20$ & 1.18 & $1.70 \mathrm{E}-11$ \\
\hline 525586882 & Endo-beta-1,4-xylanase & Y & $\mathrm{GH} 10$ & 1.58 & 9.90E-20 & 3.40 & $9.90 \mathrm{E}-20$ \\
\hline 525584853 & Endo-beta-1,6-galactanase & Y & $\mathrm{GH} 30$ & 0.20 & 7.77E-16 & 0.01 & 0.0061322 \\
\hline 525588065 & Exo-beta-1,3-galactanase & Y & $\mathrm{GH} 43$ & 2.88 & 2.70E-06 & 2.23 & 3.47E-06 \\
\hline 525581916 & Exo-beta-1,3-glucanase & Y & $\mathrm{GH} 17$ & 0.55 & 0.0025449 & 0.46 & 0.4394613 \\
\hline
\end{tabular}

nd not detected; $\mathrm{Y}$ means with signal peptides; $G H$ glycoside hydrolase.

xylan was designed to simulate plant biomass to study these questions.

As reported previously [29], the cellulase activity (FPase and CMCase) induced from P. oxalicum GZ-2 by the mixture of cellulose and xylan was significantly higher than that induced by purified cellulose. However, few reports have sought to explain why a mixture of xylan and cellulose enhances cellulase production. Contrary to T. reesei RUT-C30, purified cellulose is a poor inducer of cellulase production for $P$. oxalicum GZ-2. The result suggested that a difference potentially exists between these two strains in their production and regulation of cellulases. Another possible explanation is that $T$. reesei RUT-C30 is a mutant strain lacking repression by glucose, whereas $P$. oxalicum GZ-2 is not. In the A culture supernatant of strain GZ-2, a low concentration of glucose was detected during the fermentation period, which can repress the expression of cellulase. Wei et al. reported that a cataboliterepression-resistant mutant strain (Penicillium decumbens JU-A10) has a higher secretion capacity for cellulolytic enzymes than the wild-type strain Penicillium decumbens 114-2 [30]. Therefore, it is not surprising that T. reesei RUT-C30 produces cellulolytic enzymes more efficiently on cellulose medium.

The growth behavior of strain GZ-2 with various substrates was determined to evaluate the effect of fungal growth on enzymatic activity. The fungal cells of strain GZ-2 grew on the AX medium slightly faster than on the other substrates during the first three days (no significant difference at $P<0.05$ ), whereas the biomass of the A treatment was increased gradually and peaked at the end of fermentation. This may have happened because the low concentration reducing sugar was constantly supplemented as nutrition for growth from the enzymatic hydrolysis of A (data not shown). These results suggested that the increase in lignocellulolytic enzyme activity was not caused by better growth with the mixed carbon source.

The CMCase activity significantly increased when $x y-$ lan was added to the cellulose medium; however, the culture supernatant of $\mathrm{X}$ did not display any CMCase activity. It was obvious that the increased CMCase activity was not due to xylan induction. We conjecture that xylan or its derivative products may activate regulatory factors that are able to enhance cellulase and hemicellulase expression. The xylanase regulator has been identified in Trichoderma reesei (xyr1) [31,32] and Aspergillus niger $(X \ln R)[33,34]$ as the main transcriptional activator regulating most xylanolytic and some cellulolytic enzyme genes. $X \ln R$ plays a key role in the xylan-triggered induction of cellulase and hemicellulase. For example, D-xylose and cellobiose trigger XlnR-dependent expression of xylanolytic and cellulolytic genes in A. oryzae [35]. Low cellulase activity was detected in the $G$ culture, suggesting that $\mathrm{G}$ weakly induced cellulose-degrading enzymes. One cellulase protein (beta-glucosidase BGL1, 525581542) and six hemicellulases in the $G$ secretome further confirmed the result of enzymatic activity. This result is not difficult to understand because low constitutive enzyme expression is necessary to initiate the formation of soluble sugars as inducers. Various monosaccharides and disaccharides derived from cellulosic biomass, such as Dxylose, cellobiose, gentiobiose, sophorose, and lactose, have been proposed to be cellulase inducers in different fungi [36-39].

Results of the quantitative polymerase chain reaction (q-PCR) for cellulolytic genes clearly showed that most 
genes (egl1, egl2, egl3, sow, and cbh2) were strongly expressed when AX was used as the substrate, explaining the high level of cellulase activity in the culture supernatant of AX. As we know, biomass-degrading enzymes are mainly regulated at the transcript level [40]. Significantly higher transcript levels of egl1, egl2, and egl3 were measured in the AX treatment, indicating that these enzymes were major proteins in the control of CMCase activity. The expression level of $c b h 2$ is remarkably high compared with that of other genes. Consistent with the transcript result, the most abundant protein band (C3) observed on SDS-PAGE (Figure 2) and zymography gel (Figure 3A1) was identified as cellobiohydrolase, and this protein is a main cellulase in Penicillium decumbens 114-2 [41]. It is indicated that the enzyme cellobiohydrolase II (encoded by $c b h 2$ ) was also the major cellulase in the strain GZ-2. The transcript level of $c b h 2$ was significantly higher in the AX culture among the four substrates, suggesting that the cellobiohydrolase II was strongly induced by AX. In most fungi, including $T$. reesei and $P$. oxalicum, cellobiohydrolase is the main cellulase in the cellulolytic system [41,42]. Unexpectedly, the best substrate for beta-glucosidase production was $\mathrm{X}$ instead of $\mathrm{A}$ or $\mathrm{AX}$, and this was confirmed by the high transcript level of the beta-glucosidase gene $b g l$ and the bright hydrolysis zone in-gel activity detection. Jørgensen et al. reported a similar result in which oat spelt xylan induced more beta-glucosidase than cellulose for Penicillium persicinum IBT 13226 [29]. For the cellobiohydrolase activity gel, a bright band was observed in lanes AX, suggesting that abundant cellobiohydrolase was present in the AX secretome. This result is consistent with the results of enzyme assay and gene expression.

A greater number of higher intensity protein bands were observed in the AX lane than in other lanes, indicating that the addition of xylan to the cellulose medium clearly changed the extracellular protein profiles. To compare the secretion patterns of (hemi)cellulolytic enzymes, zymogram gels incorporated with sodium carboxymethyl cellulose (CMC-Na) or beechwood xylan were run. Zymography is a powerful technology compared to the traditional colorimetric method because it not only can measure enzymatic activity but also visualize hydrolytic enzymes [43]. Using zymography, Liu et al. found that rice straw induces more protein bands with CMCase and xylanase activity than does Avicel [23]. The same number of bands with CMCase activity between lanes A and AX and the bigger pale-red hydrolysis zones of lane AX together indicated that the higher CMCase activity induced by AX was not due to a change of the protein species but instead to increased protein content. This result was further confirmed by the LC-MS/MS result that the same number of cellulases was identified in the $\mathrm{A}$ and $\mathrm{AX}$ secretomes. No
CMCase activity was detected using the 3,5-dinitrosalicylic acid (DNS) method in the G or X culture supernatant, but some CMCase-active bands were observed in the zymogram. This result suggested that zymography is more sensitive than the colorimetric method for detecting CMCase activity. Other proteins, such as alphaamylase and glucoamylase, were also identified in the zymogram by MALDI-TOF-MS/MS. These proteins may really hydrolyze CMC-Na but may not be the desired proteins with degrading ability because the excised band may contain several proteins. Therefore, to accurately identify a single protein with CMCase or xylanase activity, onedimensional zymography is not sufficient. Accordingly, two-dimensional zymography should be used [44].

It is well known that xylanase is usually induced by $x y-$ lan polymers and that cellulose is a poor substrate for producing xylanase. For example, Hori et al. reported that the addition of xylan to cellulose medium significantly increased xylanase activity and GH10 xylanase production in the basidiomycete Phanerochaete chrysosporium [45]. As expected, adding cellulose to the xylan culture medium had little effect on the xylanase production of T. reesei RUT-C30 (Additional file 1: Figure S1). However, adding cellulose to the xylan culture medium (A:X $=2: 1$ ) strongly enhanced the xylanase production of P. oxalicum GZ-2. That the highest xylanase activity was induced by the AX substrate was further confirmed by sensitive zymography analysis. However, the xylanase activity was always low during fermentation on cellulose medium, suggesting that the increased xylanase activity was not directly caused by cellulose induction. It suggests that positive synergistic effects exist in enzyme induction between A and $\mathrm{X}$ when P. oxalicum GZ-2 is grown on a complex substrate. The significantly higher expression levels of xylanase genes ( $x y l 3$ and $x y l 4)$ induced by AX suggest that two xylanases (encoded by $x y l 3$ and $x y l 4)$ are the reason for the increase in xylanase activity in the AX culture. The protein band (X10) showed the maximal hydrolysis zone (Figure 3A2), suggesting that it was the most abundant protein in the xylanase zymogram, and it was identified as GH11 xylanase II (encoded by $x y l 2$ ). The high xylanase II abundance is in agreement with its gene ( $x y l 2$ ) being strongly expressed when $\mathrm{X}$ is used as a substrate. Although the content of GH11 xylanase II (encoded by xyl2) was dominant in the $\mathrm{X}$ secretome, the specific activity of xylanase II was found to be weaker than that of the other two xylanases (encoded by $x y l 3$ and xyl4) [46]. These results supported the idea that these two xylanases (encoded by $x y l 3$ and $x y l 4$ ) are the key enzymes contributing to the high xylanase activity instead of xylanase II when cellulose is added to xylan medium. These results from the xylanase zymogram further confirmed that the addition of cellulose to xylan increased the 
abundance of hemicellulase species. Xylanase activity could be detected by neither colorimetry nor zymography when strain GZ-2 was grown on G, indicating the repression of these enzymes by glucose.

Interestingly, the secretome was significantly altered by the addition of xylan to the cellulose medium. In particular, the proportion of cellulases and hemicellulases was almost twofold higher in the AX secretome than in the others, which may be an important reason why lignocellulolytic enzyme production was enhanced when AX was used as the substrate. Three major cellulases, namely endo-1,4-beta-glucanase, exo-1,4-betaglucanase, and beta-glucosidase, were also expressed in the $\mathrm{A}$ and $\mathrm{X}$ secretomes. However, the swollenin protein (525580909), which disrupts crystalline cellulose to enhance cellulosic substrate hydrolysis, and GH7 cellobiohydrolase (525584244) were only present in the AX secretome. A similar result was reported by GómezMendoza et al., in which the expansin-like protein (like the swollenin protein) only existed in the surgarcane bagasse secretome among four secretomes (glucose, CMC, xylan, and surgarcane bagasse) of Trichoderma harzianum [47]. It is noteworthy that many hemicellulases were secreted when strain GZ-2 was grown on the medium using $\mathrm{A}$ as the carbon source. However, the hemicellulase activity (xylanase and beta-xylosidase) was maintained at a low level (Figure 1), indicating that cellulose is a poor inducer of hemicellulase production. This phenomenon is normal because the same results have been found in other fungi such as Postia placenta [48], Aspergillus fumigatus [23], and Trichoderma harzianum [47]. The putative beta-1,3-1,4-glucanase (525581794), cellobiohydrolase Cel6A (525584431), and putative GH61 cellulose monooxygenase (525585914) were significantly upregulated in the AX treatment compared to the A treatment according to the AX/A ratio. These results indicated that more diverse functional protein species and higher expression of biomass-degrading proteins lead to the greater lignocellulolytic enzyme activity from the addition of xylan to cellulose cultures. The Bray-Curtis similarity indices, dendrogram analyses, and diversity indices together demonstrated that the secretome produced by $P$. oxalicum GZ-2 strictly depended on the substrate and that strain GZ-2 directionally changed the proportion of lignocellulolytic enzymes in its secretome according to the component of the substrate to promote subsistence on the complex substrate. Hori et al. studied the effects of xylan on the secretome of the basidiomycete Phanerochaete chrysosporium cultivated on cellulose medium using two-dimensional electrophoresis [45]. These authors found a similar result in that the addition of xylan to cellulose cultures significantly increased the xylanase and Avicelase activities. However, the expression of endo-beta1,4-glucanase, beta-glucosidase, and cellobiohydrolase did not significantly increase in the mixed xylan and cellulose culture of $P$. chrysosporium. Furthermore, these authors' studies are mainly focused on xylan-degrading enzymes, but less work was conducted to investigate the cellulase effect. Gómez-Mendoza et al. comparatively studied the secretomes of Trichoderma harzianum on CMC, xylan, and sugarcane bagasse [47]. Although the sugarcane bagasse-induced secretome from Trichoderma harzianum displayed the highest cellulolytic and xylanolytic activities, it did not correspond to greater proteome complexity because the cellulose-induced secretome was even more diverse.

Many studies have demonstrated that xylan is an effective inducer of hemicellulases $[12,47,49,50]$. In this study, up to five genetically different putative endo-beta-1,4-xylanases (two GH 10, two GH 11, and one GH 30) were detected in the $\mathrm{X}$ secretome, and four xylanases were observed in the AX and A secretomes, respectively. Unexpectedly, the proportion of hemicellulases $(21.8 \%)$ in the AX treatment was increased significantly compared to that in the X (12.1\%) or A (7.6\%) treatment. Although more xylanases were induced by $\mathrm{X}, \mathrm{AX}$ induced more other hemicellulases such as alpha-L-arabinofuranosidase and acetyl xylan esterase than $\mathrm{X}$. These results indicated that these proteins have contributed to the significant increase of the xylanase activity. Liu et al. identified six genetically different endo-beta-1,4-xylanases in the Penicillium decumbens 114-2 secretome induced by a mixed medium (CW) consisting of cellulose plus wheat bran [41]. Beta-xylosidase was not detected in the P. decumbens 114-2 secretome of CW, although five genes were detected in the transcriptome. In this study, two beta-xylosidases were detected in each of the A, X, and AX secretomes, whereas only one was induced by G. These results suggest that P. oxalicum GZ-2 has more advantages in the degradation of hemicelluloses than does $P$. decumbens 114-2. Thus, many biomass-degrading enzymes are identified in the secretome, suggesting the potential of P. oxalicum GZ-2 as a versatile cell factory for the production of extracellular enzymes. Further works on molecular regulations are needed in order to understand the mechanisms of lignocellulolytic enzyme production under the induction of complex substrates.

\section{Conclusions}

In lignocellulolytic enzyme production, cellulose and $x y-$ lan have positively synergistic effects and they play an important role in the induction of highly efficient lignocellulolytic enzymes. More diverse functional protein species and the higher expression of certain enzymes are the primary contributors to the positively synergistic effect that results in greater enzymatic activity. The composition of the secretome of $P$. oxalicum GZ-2 strictly depended on the nature and component of the substrate. 
The fungus GZ-2 changed the proportion of lignocellulolytic enzymes in its secretome according to the type of substrate. These results were able to successfully explain the more highly efficient enzyme production induced by a complex substrate.

\section{Materials and methods \\ Microorganisms, growth conditions, and secretome extraction}

The P. oxalicum GZ-2 used in this study was isolated and identified as previously reported [12] and has been deposited into the China General Microbiological Culture Collection Center (CGMCC 7527). T. reesei RUT-C30 (ATCC 56765) was kindly provided by Irina S. Druzhinina (Vienna University of Technology, Vienna). The two strains were grown on potato dextrose medium at $30^{\circ} \mathrm{C}$ for 6 to 7 days. Conidia were harvested and made into a suspension at a concentration of $1 \times 10^{7}$ conidia/ $\mathrm{mL}$. For secretome production, a basal medium (2.0 g of $\mathrm{KH}_{2} \mathrm{PO}_{4}, 1.4 \mathrm{~g}$ of $\left(\mathrm{NH}_{4}\right)_{2} \mathrm{SO}_{4}, 1.0 \mathrm{~g}$ of tryptone, $0.3 \mathrm{~g}$ of urea, 0.4 g of $\mathrm{CaCl}_{2} 2 \mathrm{H}_{2} \mathrm{O}, 0.3 \mathrm{~g}$ of $\mathrm{MgSO}_{4} 7 \mathrm{H}_{2} \mathrm{O}, 7.5 \mathrm{mg}$ of $\mathrm{FeSO}_{4} 7 \mathrm{H}_{2} \mathrm{O}, 2.0 \mathrm{mg}$ of $\mathrm{MnSO}_{4} \mathrm{H}_{2} \mathrm{O}, 2.0 \mathrm{mg}$ of $\mathrm{ZnSO}_{4}$, and $3.0 \mathrm{mg}$ of $\mathrm{CoCl}_{2}$ in $1,000 \mathrm{~mL}$ of water, $\left.\mathrm{pH} 5.0\right)$ was supplemented with 1\% (w/v) cellulose (Avicel PH-101, Sigma, treatment A), xylan (beechwood xylan, Sigma, treatment $\mathrm{X}$ ), a mixture of cellulose and xylan (cellulose: xylan $=2: 1$, treatment AX), or glucose (treatment G). The ratio of $\mathrm{A}: \mathrm{X}=2: 1$ was chosen to reflect the cellulose and hemicellulose composition of the majority of agricultural residues. An aliquot of $100 \mathrm{~mL}$ of supplemented medium was placed in a $500-\mathrm{mL}$ Erlenmeyer flask, sterilized at $115^{\circ} \mathrm{C}$ for $30 \mathrm{~min}$, inoculated with $1 \mathrm{~mL}$ of conidia suspension $\left(1 \times 10^{7}\right.$ conidia $\left./ \mathrm{mL}\right)$, and incubated at $30^{\circ} \mathrm{C}$ for 7 days $(170 \mathrm{rpm})$. Each treatment was replicated three times. The fermented broths were centrifuged at $12,587 \times \mathrm{g}$ at $4^{\circ} \mathrm{C}$ for $20 \mathrm{~min}$, the precipitated material was discarded, and the supernatant was filtered through a $0.22-\mu \mathrm{m}$ membrane and further concentrated by freezedrying. One hundred micrograms of the dried powder was dissolved in $10 \mathrm{~mL}$ of $50 \mathrm{mM}$ Tris- $\mathrm{HCl}$ buffer $(\mathrm{pH}$ 8.0) and ultrafiltered through a $10-\mathrm{kDa}$ molecular weight cut-off (MWCO) membrane (Sartorius, Göttingen, Germany). The total protein content in the ultrafiltered solution was determined using a MicroBCA protein assay kit (Dingguo Changsheng Biotechnology Co., Ltd., Beijing, China) with bovine serum albumin as the standard. The protein solution was stored at $-80^{\circ} \mathrm{C}$ for later proteomic analysis.

\section{Lignocellulolytic enzyme activity and biomass assays}

During fermentation, 2-mL samples were collected at regular intervals for lignocellulolytic enzyme activity assays. The filter paper (FPase) and endoglucanase (CMCase) activities were determined as described by
Ghose [51] using Whatman grade 1 filter paper $(1.0 \times$ $6.0 \mathrm{~cm})$ and $1 \%(\mathrm{w} / \mathrm{v})$ sodium carboxymethyl cellulose (CMC-Na, Sigma, USA) as substrates, respectively. The xylanase activity was determined at $50^{\circ} \mathrm{C}$ for 10 min using beechwood xylan (1\%, w/v, Sigma, USA) as the substrate according to Bailey et al. [52]. The reducing sugars released by the enzymatic reaction were determined using the DNS method [53] with glucose or xylose as the standard. One international unit (IU) of enzyme activity was defined as the amount of enzyme releasing $1 \mu \mathrm{mol}$ of reducing sugar per minute under the assay conditions.

The beta-glucosidase, beta-xylosidase, and cellobiohydrolase activities were measured using $10 \mathrm{mM} p$-nitrophenyl-beta-D-glucopyranoside, $p$-nitrophenyl-beta- $\mathrm{D}$ xylopyranoside, and $p$-nitrophenyl beta-D-cellobioside as substrates according to Parry et al. [54]. The reaction was subsequently terminated by adding $100 \mu \mathrm{L}$ of $2 \mathrm{M}$ $\mathrm{Na}_{2} \mathrm{CO}_{3}$. A Multi-detection Microplate Reader (SpectraMax M5, Molecular Devices, Sunnyvale, CA, USA) was used to read the absorbance at $405 \mathrm{~nm}$. One unit of activity was defined as the amount of enzyme that was required to release $1 \mu \mathrm{mol}$ of nitrophenol per minute.

A separate fermentation experiment was conducted to determine the fungal biomass. The entire fermented suspension was collected ( $\mathrm{X}$ and $\mathrm{G}$ ), filtered through dried filter paper, washed with MilliQ water (Millipore, Bedford, MA, USA) three times, and dried at $75^{\circ} \mathrm{C}$ to constant weight. The mycelial weight (A or AX) was calculated as the difference between the total dry weight of the solids (mycelium and residual cellulose) and that of the residual cellulose. The content of residual cellulose was determined according to Ahamed and Vermette [55].

\section{Protein profiles analysis using zymography and MALDI-TOF-MS/MS}

Proteins in the ultrafiltered solution were profiled using SDS-PAGE $(11 \%(\mathrm{w} / \mathrm{v})$ polyacrylamide gel with a $5 \%$ stacking gel) as described by Laemmli [56] by loading approximately $100 \mu \mathrm{g}$ of protein. The endoglucanase and xylanase activities were analyzed by zymogram according to Peterson et al. [57]. To do this, the polyacrylamide gel was incorporated with $1 \% \mathrm{CMC}$ and xylan as substrates [23]. Both the SDS-PAGE and zymogram gels were run in the Mini-Protean II system (Bio-Rad) for 120 to $180 \mathrm{~min}$ at $120 \mathrm{~V}$. The zymogram gel was stained with $0.1 \%(\mathrm{w} / \mathrm{v})$ Congo red solution for $30 \mathrm{~min}$ followed by destaining with $1 \mathrm{M} \mathrm{NaCl}$. To identify the proteins, the protein spots of interest were excised and in-gel digested with trypsin according to Liu et al. [23]. The digested proteins were identified using Bruker ultrafleXtreme MALDI-TOF-MS/MS (Bruker Daltonics, Karlsruhe, Germany). The protein candidates were searched in a proteome database of Penicillium oxalicum 114-2 that was 
downloaded from the National Center for Biotechnology Information (NCBI) database [58] using Mascot (Matrix Science, London, UK). The search parameters were set as follows: taxonomy fungi, enzyme trypsin, allow up to one missed cleavage, carbamidomethylation of cysteines as fixed modification, oxidation of methionine as variable modification, peptide mass tolerance of $120 \mathrm{ppm}$, and MS/MS tolerance of 0.6 Da. The identification of the proteins was considered positive when the Mascot score was $P<0.05$.

\section{RNA extraction and real-time quantitative PCR}

For total RNA extraction, fresh mycelia of $P$. oxalicum GZ-2 induced under different carbon sources at $30^{\circ} \mathrm{C}$ for $48 \mathrm{~h}$ were ground in liquid nitrogen and suspended in Trizol reagent (Invitrogen, Carlsbad, CA, USA). The total RNA was extracted following the manufacturer's protocol. Reverse transcription (RT) was performed using the PrimeScript ${ }^{\mathrm{Tm}}$ RT reagent Kit and the gDNA Eraser Kit (Takara, Dalian, China). The RNA concentration was determined at $260 \mathrm{~nm}$ using a NanoDrop ND2000 (Thermo Fisher Scientific, Wilmington, DE).

To determine the expression of lignocellulose-degrading genes, real-time quantitative PCR (q-PCR) was performed using the primers listed in Additional file 7: Table S4. Seven known genes encoding cellulose-degrading enzymes were studied in this work, namely three endoglucanase genes (egl1, KF233750; egl2, KF233751; and egl3, KF233752), one beta-glucosidase gene ( $b g l$, KF233746), one swollenin gene (sow, KF233754), and two cellobiohydrolase genes (cbh1, KF233748; and cbh2, KF233749). Seven known genes encoding hemicellulose-degrading enzymes were selected, including four xylanase genes ( $x y l 1$, KF233755; $x y l 2$, KF233756; $x y l 3$, KF233757; and $x y l 4$, KF233758), one beta-xylosidase gene (b-x, KF233747), one alpha-L-arabinofuranosidase gene ( $\operatorname{arf}$, KF233745), and one beta-1-4-mannanase gene ( $m a$, KF233753). The gene expression copy number was calculated using a standard curve for each gene as described by Lee et al. [59]. The transcript number of the actin gene was quantified as an internal standard using the following primers: actin-F (CTCCATCCAGGCCGTTCTG) and actin-R (CATGAGGTAGTCGGTCAAGTCAC).

\section{Protein digestion, peptide extraction, and mass spectrometric analysis}

Equal amounts of protein $(2.0 \mathrm{mg})$ from each experimental condition were denatured in $1 \mathrm{~mL}$ of $8 \mathrm{M}$ urea and reduced in $5 \mathrm{mM}$ dithiothreitol (DTT) in $50 \mathrm{mM}$ Tris- $\mathrm{HCl}(\mathrm{pH} 8.0)$ at $95^{\circ} \mathrm{C}$ for $20 \mathrm{~min}$. After cooling to room temperature, the protein was alkylated in $25 \mathrm{mM}$ iodoacetamide (IAA) for $45 \mathrm{~min}$ in the darkness at room temperature. The final products were digested by adding 2\% sequencing-grade trypsin (Promega, Madison, WI,
USA) in urea (1.0 M)- $\mathrm{NH}_{4} \mathrm{HCO}_{2}(50 \mathrm{mM})(\mathrm{pH} 7.8)$ at $37^{\circ} \mathrm{C}$ for $18 \mathrm{~h}$. The peptide mixtures after digestion were lyophilized, desalted by Empore C18-SD disk cartridge (7 mm/3 mL, $3 \mathrm{M}$, Chrom Tech, Apple Valley, MN, USA) and further dried in a vacuum centrifuge.

The dried peptides were resuspended in $200 \mu \mathrm{L}$ of $0.1 \%$ formic acid and separated by an Acclaim PepMap 100 column (C18, $3 \mu \mathrm{m}, 100 \AA$ ) (Dionex, Sunnyvale, CA, USA) capillary with a $15-\mathrm{cm}$ bed length using an UltiMate 3000 nano-HPLC (Thermo Fisher Scientific, San Jose, CA, USA) at a flow rate of $300 \mathrm{~nL} / \mathrm{min}$ linked to an LTQ Orbitrap XL mass spectrometer (Thermo Scientific, San Jose, CA, USA). Two solvents, A $(0.1 \%$ formic acid) and B (aqueous 80\% acetonitrile in $0.08 \%$ formic acid), were used to elute the peptides from the nanocolumn. The gradient elutions were achieved using 5 to $40 \%$ of solvent B for $32 \mathrm{~min}, 40$ to $95 \%$ B for 19 min, and maintained at $95 \%$ B for $9 \mathrm{~min}$, with a total run time of $60 \mathrm{~min}$. The electrospray voltage and the temperature of the ion transfer capillary were $2.2 \mathrm{kV}$ and $200^{\circ} \mathrm{C}$, respectively. The LTQ Orbitrap XL mass spectrometer was run in data-dependent acquisition mode using Xcalibur 2.2 software (Thermo Scientific) using the positive ion mode for data acquisition. Full-scan MS spectra (from m/z 350 to 1800) were acquired in the Orbitrap with a resolution of 60,000 . The 10 most intense precursor ions greater than the threshold of 500 counts were selected for collision-induced fragmentation in the linear ion trap at a normalized collision energy of $35 \%$. Dynamic exclusion was employed within $60 \mathrm{~s}$ to prevent the repetitive selection of peptides. A total of four technical replications were obtained for each biological replicate.

\section{Mass spectrometric data search and label-free quantitative analysis}

All the MS/MS spectra were matched to specific proteins by searching against the FASTA proteome database of Penicillium oxalicum 114-2 that was downloaded from the NCBI database [58] using Proteome Discoverer software 1.3 (Thermo Scientific). Oxidation (M) was set as the dynamic modification; carbamidomethylation (C) was used as the static modification. The search results were filtered by a false discovery rate of 0.05 using a decoy database search. Protein identifications were accepted at $>95 \%$ probability and contained at least one uniquely matched peptide. The signal peptide sequences were analyzed using the signal peptide prediction program SignalP version 4.1 [60]. The molecular mass and isoelectric point values were theoretical values obtained from the Compute $\mathrm{pI} / \mathrm{Mw}$ tool [61] according to predicted amino acid sequences. PRIMER software (version 5.2.8, Plymouth Routines In Multivariate Ecological Research, PRIMER-E Ltd, Plymouth, UK) was used to analyze the 
Bray-Curtis similarity indices. The Bray-Curtis similarity indices were determined based on the detection or nondetection of a protein that was identified by LC-MS/MS in the secretome. A dendrogram was also generated using the PRIMER software.

For the quantitative analysis, SIEVE (Version 2.0, Thermo Fisher Scientific), a commercial label-free quantification package, was used to compare the relative abundance of proteins between the different carbon source treatments. Four raw MS files from each treatment were analyzed using the SIEVE software according to Katz et al. [62]. The experimental workflow of SIEVE is described as follows. First, align the chromatographic peaks that were detected by MS. Second, develop frames on all the parent ions that were scanned by MS/MS. Third, compare the area of the chromatographic peak of each sample within a frame and determine the ratios between two sample groups in a frame. Finally, identify all the frames with an MS/MS scan by importing the SEQUEST search results.

\section{Statistical analysis}

The experiments were carried out in triplicate, and the results were subjected to Tukey's HSD test for three independent samples at a $5 \%$ or $1 \%$ level of significance $(P \leq 0.05$ or 0.01$)$. All of the statistical analyses were performed using SPSS version 19.0 (SPSS Institute Inc., Cary, NC) and Microsoft office excel 2010. The LC-MS/MS alignment results are listed in Additional file 8.

\section{Additional files}

Additional file 1: Figure S1. Lignocellulolytic enzyme activities in the culture supernatant and fungal biomass of T. reesei RUT-C3O in the presence of different substrates for 6 days at $30^{\circ} \mathrm{C}$. The activities of FPase, CMCase, xylanase, and biomass are listed in A, B, C, and D, respectively. The error bars indicate the standard deviation of three replicates. Values in different treatments followed by the same letter are not significantly different according to Tukey's honest significant difference test $(P<0.05)$.

Additional file 2: Figure S2. Fungal biomass $(A)$ and protein concentration (B) analysis of $P$. oxalicum GZ-2 in the presence of various substrates during submerged fermentation for 7 days at $30^{\circ} \mathrm{C}$. The error bars indicate the standard deviation of three replicates.

Additional file 3: Table S1. The common proteins identified in all four treatments.

Additional file 4: Table S2. The identified proteins in secretomes induced by various substrates.

Additional file 5: Figure S3. Distribution of the identified proteins according to molecular mass and isoelectric point. Both the molecular mass and isoelectric point are theoretical values obtained from the Compute pl/Mw tool according to predicted amino acid sequences.

Additional file 6: Table S3. The Simpson and Shannon-Wiener indices. Additional file 7: Table S4. Primers used for q-PCR in this study Additional file 8: Table S5. The LC-MS/MS identification results.

\section{Abbreviations}

A: Avicel; AX: mixture of Avicel and xylan; $\mathrm{CBH}$ : cellobiohydrolase:

CMCase: carboxymethyl cellulase or endoglucanase; CMC-Na: sodium carboxymethyl cellulose; D index: Simpson diversity index; DNS: 3,5dinitrosalicylic acid; DTT: dithiothreitol; FPase: filter paper activity; G: glucose; GH: glycoside hydrolase; H index: Shannon-Wiener index; LC-MS/MS: liquid chromatography-tandem mass spectrometry; MALDI-TOF-MS/MS: matrixassisted laser desorption/ionization time-of-flight tandem mass spectrometry; MWCO: molecular weight cut-off; q-PCR: real-time quantitative polymerase chain reaction; $X$ : xylan.

\section{Competing interests}

The authors declare that they have no competing interests.

\section{Authors' contributions}

HPL performed the major experiments containing the molecular q-PCR and proteomics analysis, designed the experiment, and wrote the manuscript. SXL performed the enzyme production and the enzymatic activity assay. ZW helped to revise the manuscript. YCX was the corresponding author; he and QRS supervised the work and contributed to the manuscript. All authors read and approved the final manuscript.

\section{Acknowledgements}

We express our appreciation to professor Yin (Shixue YIN, Yangzhou University), associate professor Raza Waseem, and Dr. Dongyang LIU (Nanjing Agricultural University) for carefully discussing and revising our manuscript. We thank Dr. Dai (Shen DAI, Nanjing Agricultural University, Life Science Test Center) for the mass-spectrometric analysis and operation. This research was financially supported by the Agricultural Ministry of China (2011-G27), Special Fund for Agro-scientific Research in the Public Interest (201203001), National Key Technologies R\&D Program (L020130249) and the 111 project (B12009) and Qing Lan Project.

Received: 24 July 2014 Accepted: 21 October 2014

Published online: 18 November 2014

\section{References}

1. Martinez D, Berka RM, Henrissat B, Saloheimo M, Arvas M, Baker SE, Chapman J, Chertkov O, Coutinho PM, Cullen D: Genome sequencing and analysis of the biomass-degrading fungus Trichoderma reesei (syn. Hypocrea jecorina). Nat Biotechnol 2008, 26:553-560.

2. Merino ST, Cherry J: Progress and challenges in enzyme development for biomass utilization. In Biofuels. Edited by Lisbeth O. Springer Berlin Heidelberg: Springer; 2007:95-120.

3. Marjamaa K, Toth K, Bromann PA, Szakacs G, Kruus K: Novel Penicillium cellulases for total hydrolysis of lignocellulosics. Enzyme Microb Technol 2013, 52:358-369.

4. Liming X, Xueliang S: High-yield cellulase production by Trichoderma reesei ZU-02 on corn cob residue. Bioresour Technol 2004, 91:259-262.

5. Fang $X$, Yano $S$, Inoue $H$, Sawayama S: Lactose enhances cellulase production by the filamentous fungus Acremonium cellulolyticus. I Biosc Bioeng 2008, 106:115-120.

6. Mandels M, Reese ET: Induction of cellulase in fungi by cellobiose. J Bacteriol 1960, 79:816.

7. Sternberg D, Mandels GR: Induction of cellulolytic enzymes in Trichoderma reesei by sophorose. J Bacteriol 1979, 139:761-769.

8. Morikawa Y, Ohashi T, Mantani O, Okada H: Cellulase induction by lactose in Trichoderma reesei PC-3-7. Appl Microbiol Biotechnol 1995, 44:106-111.

9. Karaffa L, Fekete E, Gamauf C, Szentirmai A, Kubicek CP, Seiboth B: D-Galactose induces cellulase gene expression in Hypocrea jecorina at low growth rates. Microbiology 2006, 152:1507-1514.

10. Do Vale LH, Gómez-Mendoza DP, Kim MS, Pandey A, Ricart CA, Edivaldo Filho XF, Sousa MV: Secretome analysis of the fungus Trichoderma harzianum grown on cellulose. Proteomics 2012, 12:2716-2728.

11. Royer JC, Nakas J: Interrelationship of xylanase induction and cellulase induction of Trichoderma longibrachiatum. Appl Environ Microbiol 1990, $56: 2535-2539$

12. Liao H, Xu C, Tan S, Wei Z, Ling N, Yu G, Raza W, Zhang R, Shen Q, Xu Y: Production and characterization of acidophilic xylanolytic enzymes from Penicillium oxalicum GZ-2. Bioresour Technol 2012, 123:117-124.

13. Fujii T, Fang $X$, Inoue H, Murakami K, Sawayama S: Enzymatic hydrolyzing performance of Acremonium cellulolyticus and Trichoderma reesei against three lignocellulosic materials. Biotechnol Biofuels 2009, 2:1-8. 
14. Rana V, Eckard AD, Teller P, Ahring BK: On-site enzymes produced from Trichoderma reesei RUT-C30 and Aspergillus saccharolyticus for hydrolysis of wet exploded corn stover and loblolly pine. Bioresour Technol 2014, 154:282-289.

15. Juhasz T, Szengyel Z, Reczey K, Siika-Aho M, Viikari L: Characterization of cellulases and hemicellulases produced by Trichoderma reesei on various carbon sources. Process Biochem 2005, 40:3519-3525.

16. Alriksson B, Rose SH, van Zyl WH, Sjöde A, Nilvebrant N-O, Jönsson LJ: Cellulase production from spent lignocellulose hydrolysates by recombinant Aspergillus niger. Appl Environ Microbiol 2009, 75:2366-2374.

17. Li J, Lin L, Li H, Tian C, Ma Y: Transcriptional comparison of the filamentous fungus Neurospora crassa growing on three major monosaccharides D-glucose, D-xylose and L-arabinose. Biotechnol Biofuels 2014, 7:1-15.

18. Jourdier E, Cohen C, Poughon L, Larroche C, Monot F, Chaabane FB: Cellulase activity mapping of Trichoderma reesei cultivated in sugar mixtures under fed-batch conditions. Biotechnol Biofuels 2013, 6:79-91.

19. Andersen MR, Vongsangnak W, Panagiotou G, Salazar MP, Lehmann L, Nielsen J: A trispecies Aspergillus microarray: comparative transcriptomics of three Aspergillus species. Proc Natl Acad Sci U S A 2008, 105:4387-4392.

20. Delmas S, Pullan ST, Gaddipati S, Kokolski M, Malla S, Blythe MJ, Ibbett R, Campbell M, Liddell S, Aboobaker A: Uncovering the genome-wide transcriptional responses of the filamentous fungus Aspergillus niger to lignocellulose using RNA sequencing. PLoS Genet 2012, 8:e1002875.

21. Munster JMv, Daly P, Delmas S, Pullan ST, Blythe MJ, Malla S, Kokolski M, Noltorp E, Wennberg K, Fetherston R: The role of carbon starvation in the induction of enzymes that degrade plant-derived carbohydrates in Aspergillus niger. Fungal Genet Biol 2014

22. De Souza WR, Maitan-Alfenas GP, de Gouvêa PF, Brown NA, Savoldi M, Battaglia E, Goldman MHS, de Vries RP, Goldman GH: The influence of Aspergillus niger transcription factors AraR and $\mathrm{X} \ln \mathrm{R}$ in the gene expression during growth in D-xylose, L-arabinose and steam-exploded sugarcane bagasse. Fungal Genet Biol 2013, 60:29-45.

23. Liu D, Li J, Zhao S, Zhang R, Wang M, Miao Y, Shen Y, Shen Q: Secretome diversity and quantitative analysis of cellulolytic Aspergillus fumigatus Z5 in the presence of different carbon sources. Biotechnol Biofuels 2013, 6:149.

24. Saykhedkar S, Ray A, Ayoubi-Canaan P, Hartson SD, Prade R, Mort AJ: A time course analysis of the extracellular proteome of Aspergillus nidulans growing on sorghum stover. Biotechnol Biofuels 2012, 5:1-36.

25. Horta MAC, Vicentini R, da Silva DP, Laborda P, Crucello A, Freitas S, Kuroshu RM, Polikarpov I, da Cruz Pradella JG, Souza AP: Transcriptome profile of Trichoderma harzianum IOC-3844 induced by sugarcane bagasse. PLoS One 2014, 9:e88689.

26. De Souza WR, de Gouvea PF, Savoldi M, Malavazi I, de Souza Bernardes LA Goldman MHS, de Vries RP, de Castro Oliveira JV, Goldman GH: Transcriptome analysis of Aspergillus niger grown on sugarcane bagasse. Biotechnol Biofuels 2011, 4:1-17.

27. Adav SS, Li AA, Manavalan A, Punt P, Sze SK: Quantitative iTRAQ secretome analysis of Aspergillus niger reveals novel hydrolytic enzymes. J Proteome Res 2010, 9:3932-3940.

28. Alvira P, Gyalai-Korpos M, Barta Z, Oliva JM, Réczey K, Ballesteros M: Production and hydrolytic efficiency of enzymes from Trichoderma reesei RUTC30 using steam pretreated wheat straw as carbon source. J Chem Technol Biotechnol 2013, 88:1150-1156.

29. Jorgensen $H$, Morkeberg A, Krogh KBR, Olsson L: Production of cellulases and hemicellulases by three Penicillium species: effect of substrate and evaluation of cellulase adsorption by capillary electrophoresis. Enzyme Microb Technol 2005, 36:42-48.

30. Wei X, Zheng K, Chen M, Liu G, Li J, Lei Y, Qin Y, Qu Y: Transcription analysis of lignocellulolytic enzymes of Penicillium decumbens 114-2 and its catabolite-repression-resistant mutant. C R Biol 2011, 334:806-811.

31. Mach-Aigner AR, Pucher ME, Steiger MG, Bauer GE, Preis SJ, Mach RL: Transcriptional regulation of xyr1, encoding the main regulator of the xylanolytic and cellulolytic enzyme system in Hypocrea jecorina. Appl Environ Microbiol 2008, 74:6554-6562.

32. Furukawa $T$, Shida $Y$, Kitagami N, Mori K, Kato M, Kobayashi T, Okada $H_{\text {, }}$ Ogasawara W, Morikawa Y: Identification of specific binding sites for XYR1, a transcriptional activator of cellulolytic and xylanolytic genes in Trichoderma reesei. Fungal Genet Biol 2009, 46:564-574.

33. Gielkens MM, Dekkers E, Visser J, de Graaff LH: Two cellobiohydrolaseencoding genes from Aspergillus niger require D-xylose and the xylanolytic transcriptional activator XInR for their expression. Appl Environ Microbiol 1999, 65:4340-4345.

34. Van Peij NN, Gielkens MM, de Vries RP, Visser J, de Graaff LH: The transcriptional activator $\mathrm{X} \ln \mathrm{R}$ regulates both xylanolytic and endoglucanase gene expression in Aspergillus niger. Appl Environ Microbiol 1998, 64:3615-3619.

35. Stricker AR, Steiger MG, Mach RL: Xyr1 receives the lactose induction signal and regulates lactose metabolism in Hypocrea jecorina. FEBS Lett 2007, 581:3915-3920.

36. Mach-Aigner AR, Pucher ME, Mach RL: D-Xylose as a repressor or inducer of xylanase expression in Hypocrea jecorina (Trichoderma reesei). Appl Environ Microbiol 2010, 76(6):1770-1776.

37. Marui J, Tanaka A, Mimura S, de Graaff LH, Visser J, Kitamoto N, Kato M, Kobayashi T, Tsukagoshi N: A transcriptional activator, AoXInR, controls the expression of genes encoding xylanolytic enzymes in Aspergillus oryzae. Fungal Genet Biol 2002, 35:157-169.

38. Kurasawa T, Yachi M, Suto M, Kamagata Y, Takao S, Tomita F: Induction of cellulase by gentiobiose and its sulfur-containing analog in Penicillium purpurogenum. Appl Environ Microbiol 1992, 58:106-110.

39. Stricker AR, Grosstessner-Hain K, Würleitner E, Mach RL: Xyr1 (xylanase regulator 1) regulates both the hydrolytic enzyme system and D-xylose metabolism in Hypocrea jecorina. Eukaryot Cell 2006, 5:2128-2137.

40. Tani S, Kawaguchi T, Kobayashi T: Complex regulation of hydrolytic enzyme genes for cellulosic biomass degradation in filamentous fungi. Appl Microbiol Biotechnol 2014, 98:4829-4837.

41. Liu G, Zhang L, Wei X, Zou G, Qin Y, Ma L, Li J, Zheng H, Wang S, Wang C: Genomic and secretomic analyses reveal unique features of the lignocellulolytic enzyme system of Penicillium decumbens. PLoS One 2013, 8:e55185.

42. IImen M, Saloheimo A, Onnela M-L, Penttilä ME: Regulation of cellulase gene expression in the filamentous fungus Trichoderma reesei. Appl Environ Microbiol 1997, 63:1298-1306.

43. Vandooren J, Geurts N, Martens E, Van den Steen PE, Opdenakker G: Zymography methods for visualizing hydrolytic enzymes. Nat Meth 2013, 10:211-220

44. Kim KH, Brown KM, Harris PV, Langston JA, Cherry JR: A proteomics strategy to discover $\beta$-glucosidases from Aspergillus fumigatus with twodimensional page in-gel activity assay and tandem mass spectrometry. $J$ Proteome Res 2007, 6:4749-4757.

45. Hori C, Igarashi K, Katayama A, Samejima M: Effects of xylan and starch on secretome of the basidiomycete Phanerochaete chrysosporium grown on cellulose. FEMS Microbiol Lett 2011, 321:14-23.

46. Liao H, Sun S, Wang P, Bi W, Tan S, Wei Z, Mei X, Liu D, Raza W, Shen Q: A new acidophilic endo- $\beta-1,4$-xylanase from Penicillium oxalicum: cloning, purification, and insights into the influence of metal ions on xylanase activity. J Ind Microbiol Biotechnol 2014, 41:1071-1083.

47. Gómez-Mendoza DP, Junqueira M, Do Vale LHF, Domont GB, Filho EXF, Sousa MVD, Ricart CAO: Secretomic survey of Trichoderma harzianum grown on plant biomass substrates. J Proteome Res 2014, 13(4):1810-1822.

48. Martinez D, Challacombe J, Morgenstern I, Hibbett D, Schmoll M, Kubicek $C P$, Ferreira P, Ruiz-Duenas FJ, Martinez AT, Kersten P: Genome, transcriptome, and secretome analysis of wood decay fungus Postia placenta supports unique mechanisms of lignocellulose conversion. Proc Natl Acad Sci U S A 2009, 106:1954-1959.

49. Bailey MJ, Buchert J, Viikari L: Effect of $\mathrm{pH}$ on production of xylanase by Trichoderma reesei on xylan- and cellulose-based media. Appl Biochem Biotechnol 1993, 40:224-229.

50. Chávez R, Bull P, Eyzaguirre J: The xylanolytic enzyme system from the genus Penicillium. J Biotechnol 2006, 123:413-433.

51. Ghose T: Measurement of cellulase activities. Pure App/ Chem 1987, 59:257-268.

52. Bailey MJ, Biely P, Poutanen K: Interlaboratory testing of methods for assay of xylanase activity. J Biotechnol 1992, 23:257-270.

53. Miller $G L$ : Use of dinitrosalicylic acid reagent for determination of reducing sugar. Anal Chem 1959, 31:426-428.

54. Parry NJ, Beever DE, Owen E, Vandenberghe I, Van Beeumen J, Bhat MK: Biochemical characterization and mechanism of action of a thermostable beta-glucosidase purified from Thermoascus aurantiacus. Biochem J 2001, 353:117-127.

55. Ahamed A, Vermette P: Culture-based strategies to enhance cellulase enzyme production from Trichoderma reesei RUT-C30 in bioreactor culture conditions. Biochem Eng J 2008, 40:399-407. 
56. Laemmli UK: Cleavage of structural proteins during the assembly of the head of bacteriophage T4. Nature 1970, 227:680-685.

57. Peterson R, Grinyer J, Nevalainen H: Extracellular hydrolase profiles of fungi isolated from koala faeces invite biotechnological interest. Mycol Prog 2011, 10:207-218.

58. The National Center for Biotechnology Information. [https://www.ncbi. nlm.nih.gov]

59. Lee $\mathrm{C}$, Lee S, Shin SG, Hwang S: Real-time PCR determination of rRNA gene copy number: absolute and relative quantification assays with Escherichia coli. Appl Microbiol Biotechnol 2008, 78:371-376.

60. Petersen TN, Brunak S, von Heijne G, Nielsen H: SignalP 4.0: discriminating signal peptides from transmembrane regions. Nat Meth 2011, 8:785-786.

61. Compute pl/Mw tool. [http://web.expasy.org/compute_pi/]

62. Katz E, Fon M, Eigenheer RA, Phinney BS, Fass JN, Lin D, Sadka A, Blumwald E: A label-free differential quantitative mass spectrometry method for the characterization and identification of protein changes during citrus fruit development. Proteome Sci 2010, 8:68.

doi:10.1186/s13068-014-0162-2

Cite this article as: Liao et al: Insights into high-efficiency lignocellulolytic enzyme production by Penicillium oxalicum GZ-2 induced by a complex substrate. Biotechnology for Biofuels 2014 7:162.

\section{Submit your next manuscript to BioMed Central and take full advantage of:}

- Convenient online submission

- Thorough peer review

- No space constraints or color figure charges

- Immediate publication on acceptance

- Inclusion in PubMed, CAS, Scopus and Google Scholar

- Research which is freely available for redistribution 